\title{
PENGARUH DIVERSIFIKASI OPERASIONAL DAN PROFITABILITAS TERHADAP STRUKTUR MODAL PADA PERUSAHAAN BUMN SEKTOR PERBANKAN YANG TERDAFTAR DI BURSA EFEK INDONESIA
}

\author{
Mohamad Ali Wairooy
}

muhamadaliwairooy@gmail.com

Politeknik Informatika Nasional Makassar

\begin{abstract}
This study aims to examine and analyze the effect of operational diversification and profitability on capital structure in state-owned banking companies listed on the Indonesia stock exchange. Data collection uses secondary data by using purposive sampling technique. The population in this study were all state-owned banking sector companies listed on the Indonesia stock exchange during the period 2008-2016 a total of 41 companies, while the sample taken met the criteria of 4 companies the number of observations for 9 years (2008-2016). The data obtained were analyzed using multiple linear regression analysis. The results showed that all hypotheses had a positive and significant effect based on the $\mathrm{F}$ test and $\mathrm{t}$ test. This means that both simultaneous and partial operational diversification and profitability have a positive and significant effect on the capital structure of state-owned banking companies listed on the Indonesia stock exchange.
\end{abstract}

Key words : Operational Diversification, Profitability, Capital Structure.

\begin{abstract}
Abstrak
Penelitian ini bertujuan untuk menguji dan menganalisis pengaruh diversifikasi operasional dan profitabilitas terhadap struktur modal pada perusahaan BUMN sektor perbankan yang terdaftar di bursa efek Indonesia. Pengumpulan data menggunakan data sekunder dengan menggunakan teknik purposive sampling. Populasi dalam penelitian ini adalah seluruh perusahaan BUMN sektor perbankan yang terdaftar di bursa efek Indonesia selama periode 2008-2016 sejumlah 41 perusahaan, sedangkan sampel yang diambil memenuhi kriteria sebanyak 4 perusahaan jumlah pengamatan selama 9 tahun (2008-2016). Data yang diperoleh dianalisis dengan menggunakan analisis regresi linear berganda. Hasil penelitian menunjukkan bahwa semua hipotesis berpengaruh positif dan signifikan berdasarkan uji $\mathrm{F}$ dan uji $\mathrm{t}$. Ini berarti bahwa baik secara simultan maupun parsial diversifikasi operasional dan profitabilitas berpengaruh positif dan signifikan terhadap struktur modal pada perusahaan BUMN sektor perbankan yang terdaftar di bursa efek Indonesia.
\end{abstract}

Kata Kunci: Diversifikasi Operasional, Profitabilitas, Struktur Modal. 


\section{PENDAHULUAN}

Perkembangan pasar bebas seperti adanya Masyarakat Ekonomi Asean (MEA), membuat persaingan usaha diantara perusahaan yang ada semakin ketat dan tajam, sehingga setiap perusahaan dituntut untuk berproduksi secara maksimal menghasilkan produkproduk yang berkualitas agar tetap unggul serta dapat bertahan dalam persaingan termasuk perusahaan Badan Usaha Milik Negara (BUMN) yang beroperasi dengan menerapkan prinsipprinsip ekonomi (ww.kompas.com).

Setiap perusahaan memiliki rencana yang disusun dalam rangka pencapaian tujuan yang telah ditetapkan. Salah satu aspek penting untuk mengimplementasikan rencana tersebut adalah rencana pembelanjaan. Kegagalan dalam rencana pembelanjaan akan menghambat aktivitas perusahaan. Sebaliknya, peraturan yang tepat akan memperlancar dalam menjalankan aktivitasnya. Keputusan pembelanjaan atau keputusan pemenuhan kebutuhan dana berhubungan dengan penentuan struktur modal.

Fenomena penelitian yang terkait diversifikasi operasional (EIRD), profitabilitas (ROA) dan struktur modal (DER) pada perusahaan BUMN sektor perbankan yang terdaftar di bursa efek Indonesia dari tahun 2014 sampai 2016. Fenomena ini dapat dilihat dari diversifikasi operasional (EIRD), profitabilitas (ROA) dan struktur modal (DER) pada perusahaan BUMN sektor perbankan yang terdaftar di bursa efek Indonesia dari tahun 2014 sampai 2016 mengalami fluktuasi (naik turun). Pada tahun 2014 diversifikasi operasional (EIRD) sebesar 8,54\%, profitabilitas (ROA) sebesar 3,53\% dan struktur modal (DER) sebesar 6,18\%, sedangkan pada tahun 2015 mengalami penurunan diversifikasi operasional (EIRD) sebesar 7,42\%, profitabilitas (ROA) sebesar $3,41 \%$ dan struktur modal (DER) sebesar 6,11\%, namun pada tahun 2016 terjadi peningkatan diversifikasi operasional (EIRD) sebesar 10,47\%, profitabilitas (ROA) sebesar 4,33\% dan struktur modal (DER) sebesar 6,76\%, ada indikasi akibat diversifikasi operasional dan profitabilitas.

Terkait dengan fenomena tersebut menggambarkan bahwa struktur modal belum optimal. Menurut Sutrisno (2013), struktur modal (capital structure) merupakan perimbangan atau perbandingan antara hutang (debt) dengan modal sendiri (equity) yang digunakan perusahaan untuk membiayai aktivanya. Struktur modal perusahaan dapat meminimumkan biaya modal ratarata tertimbang dan memaksimalkan profitabilitas. Untuk membelanjai operasi perusahaan dari hari ke hari seperti misalnya untuk memberi uang muka pada pembelian barang dagangan, membayar upah buruh dan gaji karyawan, dan biayabiaya lainnya, setiap perusahaan perlu menyediakan modal.

Modal yang telah dikeluarkan untuk membelanjai operasi perusahaan diharapkan akan dapat kembali lagi masuk dalam perusahaan dalam jangka waktu pendek melalui hasil aktiva perusahaan. Modal yang masuk bersumber dari aktivitas perusahaan akan dikeluarkan kembali guna membiayai operasi perusahaan selanjutnya. Dengan demikian peranan struktur modal yang jelas mampu mengidentifikasikan, besarnya proporsi modal pinjaman dalam struktur modal sehingga mampu meningkatkan diversifikasi operasional dan profitabilitas. 
Agar perusahaan dapat meningkatkan diversifikasi operasional dan profitabilitas perlu adanya perimbangan yang lebih mendalam, sehingga kontinuitas diversifikasi operasional dan profitabilitas yang diharapkan dapat tercapai. Untuk mengetahui situasi dan perkembangan seperti posisi modal, maka perlu diadakan analisa laporan keuangan perusahaan dengan menggunakan neraca dan laporan laba rugi perusahaan, dimana untuk mengukur struktur modal digunakan hutang dan equitas atau debt to equity ratio (DER) (Sutrisno, 2013). Tinggi rendahnya struktur modal dipengaruhi oleh tinggi rendahnya beberapa faktor seperti diversifikasi operasional dan profitabilitas.

Diversifikasi

operasional merupakan salah satu strategi yang dilakukan perusahaan untuk memperluas usahanya dengan membuka beberapa unit bisnis atau anak perusahaan baru baik dalam lini bisnis yang sama dengan yang sudah ada maupun dalam unit bisnis yang berbeda dengan bisnis inti perusahaan (Aisjah, 2014). Bagi perusahaan masalah diversifikasi operasional sangat penting. Bagi pimpinan perusahaan, diversifikasi operasional digunakan sebagai tolak ukur berhasil atau tidak perusahaan semakin tinggi diversifikasi operasional yang diperoleh oleh perusahaan, maka ada peluang untuk meningkatkan struktur modal.

Beberapa alat ukur yang digunakan untuk mengukur diversifikasi operasional yaitu dengan menghitung banyaknya jumlah segmen usaha yang dilaporkan, antara lain: indeks herfindah dilihat dari rasio penjualan segmen usaha perusahaan dan indeks enthropy atau Enthropy Index Related Diversification
(EIRD) secara bersamaan mempertimbangkan jumlah usaha yang dijalankan perusahaan, dan distribusi penjualan total melalui segmen industri. Didalam penelitian ini diversifikasi operasional akan diukur dengan menggunakan indeks enthropy/EIRD. Diversifikasi operasional yang tinggi akan dapat mendukung kegiatan operasional secara maksimal.

Profitabilitas merupakan kemampuan perusahaan memperoleh laba dalam hubungannya dengan penjulan, total aktiva maupun modal sendiri (Sartono, 2013). Bagi perusahaan masalah profitabilitas sangat penting. Bagi pimpinan perusahaan, profitabilitas digunakan sebagai tolak ukur berhasil atau tidak perusahaan semakin tinggi profitabilitas yang diperoleh oleh perusahaan, maka ada peluang untuk meningkatkan struktur modal.

Beberapa alat ukur yang digunakan untuk mengukur tingkat profitabilitas, antara lain: gross profit margin, net profit margin, return on assets (ROA) dan return on equity (ROE). Di dalam penelitian ini profitabilitas akan diukur dengan menggunakan return on assets (ROA) karena ROA mewakili rasio profitabilitas yang mengukur kemampuan perusahaan dalam menghasilkan laba dengan menggunakan total assets yang dimiliki perusahaan. Semakin tinggi nilai ROA, semakin efisien perusahaan dalam menggunakan assetsnya, dan akan menghasilkan keuntungan bagi perusahaan.

Berdasarkan penelitian terdahulu yang dikemukakan oleh Nurchanifia (2014) tentang pengaruh diversifikasi operasional dan diversifikasi geografis terhadap struktur modal pada perusahaan sektor manufaktur di bursa efek Indonesia. Hasil penelitian tersebut 
menunjukkan bahwa diversifikasi operasional tidak berpengaruh terhadap struktur modal dan diversifikasi geografis tidak berpengaruh terhadap struktur modal. Penelitian Mardiyati (2013) tentang pengaruh diversifikasi operasional dan profitabilitas terhadap struktur modal pada perusahaan manufaktur sub sektor otomotif dan komponen yang terdaftar di bursa efek Indonesia. Hasil penelitian tersebut menunjukkan bahwa diversifikasi operasional tidak berpengaruh terhadap struktur modal dan profitabilitas tidak berpengaruh terhadap struktur modal.

Berbeda dengan penelitian yang dilakukan oleh Lupitasari (2014) tentang pengaruh diversifikasi operasional dan profitabilitas terhadap struktur modal pada perusahaan proferti dan real estate di bursa efek Indonesia. Hasil penelitian tersebut menunjukkan bahwa diversifikasi operasional dan profitabilitas berpengaruh positif dan signifikan terhadap struktur modal. Penelitian Putri Ria (2015) tentang pengaruh diversifikasi operasional, profitabilitas dan struktur aktiva terhadap struktur modal pada perusahaan manufaktur sektor industri makanan dan minuman di bursa efek Indonesia.

Hasil penelitian yang membuktikan diversifikasi operasional, profitabilitas dan struktur aktiva berpengaruh positif dan signifikan terhadap struktur modal. Bukti tersebut didukung oleh penelitian Ichwan (2015) tentang pengaruh diversifikasi operasional, struktur aktiva dan profitabilitas terhadap struktur modal pada perusahaan automotive and allied product yang terdaftar di bursa efek Indonesia.

Hasil penelitian yang membuktikan diversifikasi operasional, struktur aktiva dan profitabilitas berpengaruh positif dan signifikan terhadap struktur modal. Penelitian ini adalah merujuk dari penelitian Lupitasari (2014). Adapun persamaan dan perbedaan antara penelitian ini dengan penelitian terdahulu adalah variabel yang sama dan juga objek penelitian menjadi alasan peneliti untuk memilih variabel diversifikasi operasional, profitabilitas dan pengaruhnya terhadap struktur modal karena hal tersebut merupakan hal menarik untuk dikaji lebih lanjut.

Alasan memilih tempat penelitian dikarenakan/didasarkan atas fenomena bahwa diversifikasi operasional (EIRD), profitabilitas (ROA) dan struktur modal (DER) pada perusahaan BUMN sektor perbankan yang terdaftar di bursa efek Indonesia dari tahun 2014 sampai 2016 mengalami fluktuasi (naik turun).

Diversifikasi operasional dan profitabilitas berpengaruh positif dan signifikan terhadap struktur modal menunjukkan bahwa ketika diversifikasi operasional dan profitabilitas meningkat maka struktur modal akan meningkat. Begitu pula sebaliknya apabila diversifikasi operasional dan profitabilitas rendah maka struktur modal menurun.

\section{LANDASAN TEORI}

Menurut Aisjah (2014), diversifikasi operasional merupakan salah satu strategi yang dilakukan perusahaan untuk memperluas usahanya dengan membuka beberapa unit bisnis atau anak perusahaan baru baik dalam lini bisnis yang sama dengan yang sudah ada maupun dalam unit bisnis yang berbeda dengan bisnis inti perusahaan.

Beberapa alat ukur yang digunakan untuk mengukur diversifikasi operasional yaitu dengan menghitung banyaknya 
jumlah segmen usaha yang dilaporkan, antara lain:

a. Indeks herfindahl dilihat dari rasio penjualan segmen usaha perusahaan.

b. Indeks enthropy secara bersamaan mempertimbangkan jumlah usaha yang dijalankan.

Perusahaan, dan distribusi penjualan total melalui segmen industri (Aisjah, 2014). Didalam penelitian ini diversifikasi operasional akan diukur dengan menggunakan indeks enthropy/ EIRD), adapun rumusnya adalah:

$$
\operatorname{EIRD}=\text { Pj.k In (一) Pj.k }
$$

Keterangan:

EIRD = Enthropy Index Related
Diversification
Pj.k = Proporsi penjualan total segmen
j us
In $(-)=$ Berat segmen bisnis Pj.k

\section{a. Tujuan Diversifikasi Operasional}

Menurut Ikatan Akuntansi Indonesia (2001) Pernyataan Standar Akuntansi Keuangan (PSAK) No. 5 Revisi 2009, tujuan diversifikasi operasional yaitu:

a. Volume penjualan yang dinyatakan dalam nilai uang atau unit.

b. Porsi pasar (market share) yang dinyatakan dalam prosentase dari total pasar untuk suatu produk atau jasa-jasa.

c. Laba, yang dinyatakan sebagai pembelian atas investasi.

Profitabilitas adalah kemampuan perusahaan memperoleh laba dalam hubungannya dengan penjualan, total aktiva maupun modal sendiri (Sartono, 2013). Menurut Martono (2012), profitabilitas adalah menunujukkan kemampuan perusahaan memperoleh laba atau ukuran efektivitas pengelolaan manajemen perusahaan. Menurut Lupitasari (2014), profitabilitas adalah kemampuan perusahaan untuk menghasilkan laba selama periode tertentu. Analisis rasio profitabilitas yang umum digunakan menurut Sartono (2013) adalah sebagai berikut:

1. Gross Profit Margin (GPM)

Rasio ini mengukur efisiensi pengendalian harga pokok atau biaya produksinya, mengindikasikan kemampuan perusahaan untuk berproduksi secara efisien.

2. Net Profit Margin (NPM)

Rasio ini digunakan untuk mengukur kemampuan perusahaan yang bersangkutan dalam menghasilkan laba bersih (net income) dari kegiatan operasi pokok bagi perusahaan yang bersangkutan.

3. Return on Assets (ROA)

Return on Assets (ROA) merupakan rasio yang digunakan untuk mengukur kemampuan manajemen perusahaan dalam memperoleh keuntungan (laba) secara keseluruhan. ROA dapat merefleksikan keuntungan bisnis dan efisiensi perusahaan dalam pemanfaatan total assets yang ada dalam perusahaan. Di dalam penelitian ini profitabilitas akan diukur dengan menggunakan return on assets (ROA) karena ROA mewakili rasio profitabilitas yang mengukur kemampuan perusahaan dalam menghasilkan laba dengan menggunakan total assets yang dimiliki perusahaan. Semakin tinggi nilai ROA, semakin efisien perusahaan dalam menggunakan assetsnya, dan akan menghasilkan keuntungan bagi perusahaan.

\section{Return on Equity (ROE)}

Rasio ini memperlihatkan sejauh manakah perusahaan mengelola modal sendiri (net worth) secara efektif, mengukur tingkat keuntungan dari 
investasi yang telah dilakukan pemilik modal sendiri atau pemegang saham perusahaan. Return on Equity (ROE) menunjukkan rentabilitas modal sendiri atau yang sering disebut sebagai rentabilitas usaha.

\section{b. Pengertian Struktur Modal}

Menurut Sutrisno (2013), struktur modal (capital structure) merupakan perimbangan atau perbandingan antara modal asing atau hutang dengan modal sendiri (debt to equity ratio atau DER) yang digunakan perusahaan untuk membiayai aktivanya. Debt to equity ratio (DER) merupakan rasio yang menggambarkan hutang dengan equitas dalam pendanaan perusahaan dan menunjukkan kemampuan modal sendiri perusahaan tersebut untuk memenuhi kewajibannya. DER merupakan salah satu rasio leverage yang bertujuan untuk mengukur kemampuan dari modal sendiri yang dijadikan jaminan untuk keseluruhan hutang perusahaan. Menurut Riyanto (2013), faktor-faktor struktur modal adalah:

\section{Tingkat bunga}

Pada waktu perusahaan merencanakan pemenuhan kebutuhan adalah sangat dipengaruhi oleh tingkat bunga yang berlaku pada waktu itu. Tingkat bunga akan mempengaruhi pemilihan jenis modal apa saja yang akan ditarik, apakah perusahaan akan mengeluarkan saham atau obligasi. Sebagaimana diuraikan dimuka bahwa penarikan obligasi hanya dibenarkan apabila tingkat bunganya lebih rendah dari pada "earning power" dari tambahan modal tersebut.

\section{Stabilitas dari "earning"}

Stabilitas dan besarnya "earning" yang diperoleh dari suatu perusahaan akan menentukan apakah perusahaan tersebut dibenarkan untuk menarik modal dengan beban tetap atau tidak. Suatu perusahaan yang mempunyai "earning" yang stabil akan selalu dapat memenuhi kewajiban finansialnya sebagai akibat dari penggunaan modal asing. Sebaliknya perusahaan yang mempunyai "earning" yang tidak stabil dan "unpredictable" akan menanggung risiko tidak dapat membayar beban bunga atau tidak dapat membayar angsuran-angsuran utangnya pada tahun-tahun atau keadaan yang buruk.

\section{Susunan dari aktiva}

Kebanyakan perusahaan dimana sebagian besar dari modalnya tertanam dalam aktiva tetap (fixed assets), akan mengutamakan pemenuhan kebutuhan modalnya dari modal yang permanen, yaitu modal sendiri, sedangkan modal asing sifatnya adalah sebagai pelengkap. Hal ini dihubungkan dengan adanya aturan struktur finansial konsevatif yang horizontal yang menyatakan bahwa besarnya modal sendiri hendaknya paling sedikit dapat menutup jumlah aktiva tetap pus aktiva lain yang sifatnya permanen. Dan perusahaan yang sebagian besar dari aktivanya sendiri dari aktiva lancar akan mengutamakan pemenuhan kebutuhan dananya dengan utang jangka panjang.

\section{Kadar rasio dari aktiva}

Tingkat atau kadar risiko dari setiap aktiva di dalam perusahaan adalah tidak sama. Makin panjang jangka waktu penggunaan suatu aktiva di dalam perusahaan, makin besar derajat risikonya. Dengan perkembangan dan kemajuan teknologi dan ilmu pengetahuan yang tak ada henti-hentinya, dalam artian ekonomis dapat mempercepat tidak digunakannya suatu aktiva, meskipun dalam artian teknis masih dapat digunakan, dalam hubungan 
ini kita mengenal adanya prinsip aspek risiko di dalam aktiva yang peka risiko, maka perusahaan harus lebih banyak membelanjai dengan modal sendiri, modal yang tahan risiko, dan sedapat mungkin mengurangi pembelanjaan dengan modal asing atau modal yang takut risiko. Dengan ringkas dapatlah dikatakan bahwa makin lama modal harus dikaitkan, makin tinggi derajat risikonya, makin mendesak keperluan dalam pembelanjaan seluruhnya atau sebagian besar dengan modal sendiri.

5. Besarnya jumlah modal yang dibutuhkan

Besarnya jumlah modal yang dibutuhkan juga mempunyai pengaruh terhadap jenis modal yang akan ditarik. Apabila jumlah modal yang dibutuhkan sekiranya dapat dipenuhi hanya dari satu sumber saja, maka tidaklah perlu, mencari sumber lain. Sebaliknya apabila jumlah modal yang dibutuhkan adalah sangat besar, sehingga tidak dapat dipenuhi dari satu sumber saja (misalnya dengan saham biasa), maka perlulah dicari sumber yang lain (misalnya dengan saham preferen dan obligasi). Dengan ringkas dapatlah dikatakan bahwa, apabila jumlah modal yang dibutuhkan sangat besar, maka dirasakan perlu bagi perusahaan tersebut untuk mengeluarkan beberapa golongan securities secara bersama-sama sedangkan bagi perusahaan yang membutuhkan modal yang tidak begitu besar cukup hanya mengeluarkan satu golongan securities saja.

\section{Keadaan pasar modal}

Keadaan pasar modal sering mengalami perubahan disebabkan karena adanya gelombang konjungtur, pada umumnya apabila gelombang meninggi (up swing) para investor lebih tertarik untuk menanamkan modalnya dalam saham. Berhubungan dengan itu maka perusahaan dalam rangka usaha untuk mengeluarkan atau menjual securities haruslah menyesuaikan dengan keadaan pasar modal tersebut.

\section{Sifat manajemen}

Sifat manajemen akan mempunyai pengaruh yang langsung dalam pengambilan keputusan mengenai cara pemenuhan kebutuhan dana. Seorang manajer yang bersifat optimis yang memandang masa depan yang cerah, yang mempunyai keberanian untuk mendukung risiko yang besar (risk seeker) akan lebih berani untuk membiayai pertumbuhan penjualannya dengan dana yang berasal dari utang (debt financing) meskipun metode pembelanjaan dengan hutang ini memberikan beban finansil yang tetap. Sebaliknya seorang manajer yang bersifat pesimis, yang serba takut untuk mengambil risiko (risk averter) akan lebih suka membelanjai pertumbuhan penjualannya dengan dana yang berasal dari sumber intern atau dengan modal saham (equity financing) yang tidak mempunyai beban finansial yang tetap.

\section{Besarnya suatu perusahaan}

Suatu perusahaan yang besar dimana sahamnya tersebar sangat luas, setiap perluasan modal saham hanya akan mempunyai pengaruh yang kecil terhadap kemungkinan hilangnya atau tergesernya kontrol dari pihak dominan terhadap perusahaan yang bersangkutan. Sebaiknya perusahaan yang kecil dimana sahamnya hanya terbesar dilingkungan kecil, penanaman jumlah saham akan mempunyai pengaruh yang besar terhadap kemungkinan hilangnya kontrol pihak dominan terhadap perusahaan yang bersangkutan. Dengan demikian maka 
perusahaan yang besar dimana sahamnya terbesar sangat luas akan lebih berani mengeluarkan saham baru dalam memenuhi kebutuhan hanya untuk membiayai pertumbuhan penjualan dibandingkan dengan perusahaan kecil.

\section{METODE PENELITIAN}

\section{a. Metode Analisis}

Analisis regresi linear berganda, digunakan untuk menguji dan menganalisis pengaruh ukuran perusahaan dan risiko bisnis terhadap struktur modal. Menurut Sugiyono (2017:215) dengan rumus:

$$
\mathrm{Y}=\mathrm{a}+\mathrm{b} 1 \mathrm{X} 1+\mathrm{b} 2 \mathrm{X} 2+\mathrm{e}
$$

Keterangan:

$$
\begin{aligned}
& \mathrm{Y} \quad=\text { Struktur modal } \\
& \mathrm{a} \quad=\text { Konstanta } \\
& \mathrm{b} 1-\mathrm{b} 2 \quad=\text { Koefisien regresi (parameter) } \\
& \mathrm{X} 1 \quad=\text { Diversifikasi operasional } \\
& \mathrm{X} 2 \quad=\text { Profitabilitas } \\
& \mathrm{e}=\text { Standar error (variabel pengganggu) }
\end{aligned}
$$

\section{1) Uji Hipotesis}

Uji simultan atau uji $\mathrm{F}$, digunakan untuk menguji variabel diversifikasi operasional (X1) dan profitabilitas (X2) secara simultan/bersama-sama berpengaruh terhadap struktur modal (Y).

\section{Hipotesis 1}

Ha1 : $\beta \neq 0$, Diversifikasi operasional dan profitabilitas berpengaruh positif dan signifikan terhadap struktur modal.

H01 : $\beta=0$, Diversifikasi operasional dan profitabilitas tidak berpengaruh positif dan signifikan terhadap struktur modal.

Kriteria pengambilan keputusan:
- Ha1 diterima jika nilai signifikan < dari taraf signifikan dan nilai Fhitung $>$ Ftabel (derajat bebas $/ \mathrm{df}=\mathrm{n}$ $\mathrm{k}-1)$ pada $\alpha=5 \%(0,05)$.

- H01 diterima jika nilai signifikan > dari taraf signifikan dan nilai Fhitung < Ftabel $(\mathrm{df}=\mathrm{n}-\mathrm{k}-1)$ pada $\alpha=5 \%(0,05)$.

\section{2) Uji Parsial (Uji t)}

Uji parsial atau uji $\mathrm{t}$, digunakan untuk menguji masing-masing variabel diversifikasi operasional (X1) dan profitabilitas (X2) berpengaruh terhadap struktur modal (Y).

\section{Hipotesis 2}

- Ha2 : $\beta \neq 0$, Diversifikasi operasional berpengaruh positif dan signifikan terhadap struktur modal.

- H02 : $\beta=0$, Diversifikasi operasional tidak berpengaruh positif dan signifikan ter4hadap struktur modal.

Kriteria pengambilan keputusan:

- Ha2 diterima jika nilai signifikan < dari taraf signifikan dan nilai thitung $>$ ttabel $(\mathrm{df}=\mathrm{n}-\mathrm{k}-1)$ pada $\alpha=5 \%$ $(0,05)$.

- H02 diterima jika nilai signifikan > dari taraf signifikan dan nilai hitung < ttabel $(\mathrm{df}=\mathrm{n}-\mathrm{k}-1)$ pada $\alpha=5 \%(0,05)$.

Hipotesis 3

- Ha3 : $\beta \neq 0$, Profitabilitas berpengaruh positif dan signifikan terhadap modal.

- H03 : $\beta=0$, Profitabilitas tidak berpengaruh positif dan signifikan terhadap struktur modal.

Kriteria pengambilan keputusan:

- Ha3 diterima jika nilai signifikan < dari taraf signifikan dan nilai thitung $>$ ttabel (df $=n-k-1)$ pada $\alpha=5 \%$ $(0,05)$. 
- H03 diterima jika nilai signifikan > dari taraf signifikan dan nilai thitung< ttabel $(\mathrm{df}=\mathrm{n}-\mathrm{k}-1)$ pada $\alpha=5 \%(0,05)$.

\section{3) Uji Koefisien Determinasi $\left(R^{2}\right)$}

Uji koefisien determinasi $\left(R^{2}\right)$, digunakan untuk melihat besarnya pengaruh diversifikasi operasional dan profitabilitas sebagai variabel independen terhadap struktur modal sebagai variabel devenden. Nilai $\mathrm{R}^{2}$ ini terletak antara 0 dan 1. Bila nilai $R^{2}$ mendekati 0 , berarti sedikit sekali variasi variabel dependen yang diterangkan oleh variabel independen. Jika nilai $\mathrm{R}^{2}$ bergerak mendekati 1 berarti semakin besar variasi variabel dependen yang dapat diterangkan oleh variabel independen jika ternyata dalam perhitungan nilai $\mathrm{R}^{2}$ sama dengan 0 maka ini menunjukkan bahwa variabel dependen tidak bisa dijelaskan oleh variabel independen dengan formula sebagai berikut:

$$
\begin{aligned}
& \mathrm{R}^{2}=(\mathrm{R})^{2} \\
& (\text { Ghozali, 2013) }
\end{aligned}
$$

Keterangan:

$\mathrm{R}^{2}=$ Koefisien determinasi

$\mathrm{R}=$ Koefisien korelasi

\section{HASIL DAN PEMBAHASAN}

\section{a. Analisis Regresi Linear Berganda}

Penelitian ini menggunakan model analisis regresi linear berganda untuk menguji dan menganalisis pengaruh diversifikasi operasional dan profitabilitas terhadap struktur modal. Melalui perhitungan dengan menggunakan program Statistik Product and Standart Solution (SPSS) Versi 23.00 sebagai berikut:

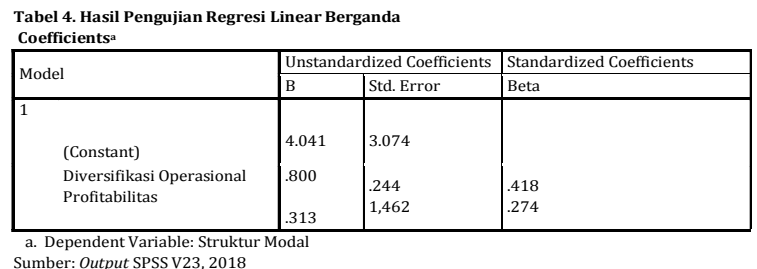

Sumber: Output SPSS V23, 2018

Berdasarkan tabel 4 di atas, diperoleh persamaan regresi linear berganda sebagai berikut:

$$
\mathrm{Y}=\mathrm{a}+\mathrm{b} 1 \mathrm{X} 1+\mathrm{b} 2 \mathrm{X} 2
$$

Dimana $: Y=4,041+0,800+0,313$

- $\mathrm{a}=4,041$, artinya jika tidak ada perubahan pada diversifikasi operasional dan profitabilitas (variabel bebas), maka nilai struktur modal sebesar 4,041 sebagai nilai konstan untuk (variabel terikat).

- $\mathrm{b}_{1}=0,800$, berarti ketika diversifikasi operasional naik $1 \%$ akan mempengaruhi peningkatan struktur modal sebesar 0,800 .

- $\mathrm{b}_{2}=0,313$, berarti ketika profitabilitas naik 1\% akan mempengaruhi peningkatan struktur modal sebesar 0,313 .

ANOVAa
\begin{tabular}{|l|l|l|l|l|l|l|}
\hline \multicolumn{2}{|l|}{ Model } & $\begin{array}{l}\text { Sum of } \\
\text { Squares }\end{array}$ & Df & $\begin{array}{l}\text { Mean } \\
\text { Square }\end{array}$ & F & Sig. \\
\hline 1 & Regression & 488.623 & 2 & 244.312 & 9.464 & $.000^{\text {b }}$ \\
\hline & Residual & 1161.692 & 33 & 35.203 & & \\
\hline & Total & 1650.315 & 35 & & & \\
\hline
\end{tabular}

a. Dependent Variable: Struktur Modal

b. Predictors: (Constant), Diversifikasi Operasional dan Profitabilitas Sumber: Output SPSS V23, 2018

Hasil analisis regresi linear berganda memberikan gambaran bahwa variabel independen memiliki hubungan yang positif terhadap variabel dependennya yaitu tingkat pengaruh yang ditunjukkan dengan nilai koefisien diversifikasi operasional dan profitabilitas yang berhubungan positif terhadap struktur modal.

\section{b. Hasil Pengujian Hipotesis}

1) Hasil Uji Simultan (Uji F) 
Hasil uji simultan atau uji $\mathrm{F}$ merupakan uji secara bersama-sama untuk menguji siginifikan pengaruh variabel diversifikasi operasional dan profitabilitas terhadap struktur modal pada perusahaan BUMN sektor perbankan yang terdaftar di bursa efek Indonesia. Tabel berikut menggambarkan hasil uji statistik F.

Hasil Hasil pengujian hipotesis pertama (H1) dengan uji pengaruh diversifikasi operasional dan profitabilitas terhadap struktur modal. Berdasarkan tabel 4.9 di atas, hasil pengujian $\mathrm{F}$ yang dilakukan diperoleh Fhitung sebesar 9,464, sedangkan Ftabel sebesar 3,280, dengan derajat bebas (df) = n-k-1 Hasil pengujian hipotesis pertama (H1) dengan uji pengaruh diversifikasi operasional dan profitabilitas terhadap struktur modal. Berdasarkan tabel 4.9 di atas, hasil pengujian $\mathrm{F}$ yang dilakukan diperoleh Fhitung sebesar 9,464, sedangkan Ftabel sebesar 3,280, dengan derajat bebas $(\mathrm{df})=\mathrm{n}-\mathrm{k}-1$ (pada penelitian ini $\mathrm{df}=36-2-1=33$ ), tingkat signifikan $5 \%$ atau 0,05. Maka dapat disimpulkan Fhitung sebesar 9,464 > Ftabel 3,280 dan signifikan yang dilihat dari signifikansi $(0,000)$ lebih kecil dari taraf signifikansi yang disyaratkan sebesar $5 \%(0,05)$, arti secara statistik bahwa hipotesis alternatif satu (Ha1) diterima, hipotesis nol satu (H01) ditolak. Artinya diversifikasi operasional dan profitabilitas secara simultan (bersamasama) berpengaruh positif dan signifikan terhadap struktur modal.

\section{c. Hasil Uji Parsial (Uji t)}

Hasil uji statistik t pada dasarkan menunjukkan seberapa jauh pengaruh satu variabel bebas (independen) secara parsial atau individual dalam mempengaruhi variabel tidak bebas
(dependen).Tabel

berikut menggambarkan hasil uji statistik t.

\begin{tabular}{|c|c|c|c|c|c|}
\hline \multirow[t]{2}{*}{ Model } & \multicolumn{2}{|c|}{$\begin{array}{l}\text { Unstandardized } \\
\text { Coefficients }\end{array}$} & \multirow{2}{*}{\begin{tabular}{|l}
$\begin{array}{l}\text { Standardized } \\
\text { Coefficients }\end{array}$ \\
Beta \\
\end{tabular}} & \multirow[t]{2}{*}{$\mathrm{T}$} & \multirow[t]{2}{*}{ Sig. } \\
\hline & $B$ & Std. Error & & & \\
\hline (Constant) & 4.041 & 3.074 & & 1.314 & .195 \\
\hline $\begin{array}{l}\text { Diversifikasi } \\
\text { Operasional } \\
\text { Profitabilitas }\end{array}$ & $\begin{array}{l}.800 \\
.313\end{array}$ & $\begin{array}{l}.244 \\
1.462\end{array}$ & .418 & $\begin{array}{l}3.277 \\
2.146\end{array}$ & .002 \\
\hline
\end{tabular}

1) Hasil pengujian hipotesis kedua (H2) dengan uji pengaruh diversifikasi operasional (X1) terhadap struktur modal (Y)

Berdasarkan tabel 5 variabel diversifikasi operasional memiliki memiliki nilai thitung 3,277 dengan nilai signifikansi 0,002 , tingkat signifikan $5 \%$ atau 0,05 dan derajat bebas $(\mathrm{df})=$ n-k-1 (pada penelitian ini $\mathrm{df}=36-2-1=$ 33). Hal ini menunjukkan bahwa nilai thitung lebih besar dari nilai ttabel $(3,277>2,035)$ dan nilai signifikansi tersebut lebih kecil dari taraf signifikansi $5 \%$ atau $0,05 \quad(0,002<0,05)$ maka H02 ditolak dan $\mathrm{Ha} 2$ diterima. Artinya diversifikasi operasional berpengaruh positif dan signifikan terhadap struktur modal.

2) Hasil pengujian hipotesis ketiga (H3) dengan uji pengaruh profitabilitas (X2) terhadap terhadap struktur modal (Y)

Berdasarkan tabel 5 variabel profitabilitas memiliki nilai thitung 2,146 dengan nilai signifikansi 0,037, tingkat signifikan $5 \%$ atau 0,05 dan derajat bebas (df) $=n-k-1$ (pada penelitian ini $\mathrm{df}=36-2-1=33$ ). Hal ini menunjukkan bahwa nilai thitung lebih besar dari nilai ttabel $(2,146>$ $2,035)$ dan nilai signifikansi tersebut lebih kecil dari taraf signifikansi 5\% atau ${ }^{\circ} 0,05 \quad(0,037<0,05)$ maka $\mathrm{H02}$ ditolak dan $\mathrm{Ha} 2$ diterima. Artinya 
profitabilitas berpengaruh positif dan signifikan terhadap struktur modal.

\section{3) Hasil Uji Koefisien Determinasi $\left(\mathbf{R}^{\mathbf{2}}\right)$}

Koefisien determinasi $\left(\mathrm{R}^{2}\right)$

menunjukkan besarnya besarnya pengaruh diversifikasi operasional dan profitabilitas sebagai variabel independen terhadap struktur modal sebagai variabel devenden. Nilai koefisien sebesar 1 menunjukkan bahwa variabel independen yang digunakan $100 \%$ tepat (sempurna) dalam menjelaskan variasi yang terjadi pada variabel dependen. Berdasarkan hasil pengolahan data maka diperoleh nilai koefisien determinasi $\left(\mathrm{R}^{2}\right)$ sebagai berikut:

\section{Tabel 7. Hasil Uji Koefisien Determinasi $\left(\mathbf{R}^{2}\right)$}

Dependent Variable: Struktur Modal Model Summary
\begin{tabular}{|l|l|l|l|l|}
\hline Model & R & R Square & Adjusted R Square & Std. Error Of The Estimate \\
\hline 1 & $.725^{\mathrm{a}}$ & .526 & .489 & 3.088 \\
\hline
\end{tabular}

Sumber: Output SPSS V23, 2018

Berdasarkan tabel 7 menunjukkan bahwa nilai $R$ Square $\left(\mathrm{R}^{2}\right)$ yang digunakan untuk menghitung pengaruh variabel independen (X1 dan X2) terhadap variabel dependen (Y) sebesar 0,526 atau $52,60 \%$. Hal ini berarti bahwa sebesar $52,60 \%$ struktur modal dipengaruhi oleh diversifikasi operasional dan profitabilitas. Adapun 47,40\% (100\% $52,60 \%$ ) dipengaruhi oleh faktor-faktor lainnya yang tidak diteliti.

\section{1) Pengaruh Diversifikasi Operasional dan Profitabilitas Secara Simultan terhadap Struktur}

Hasil penelitian ini menunjukkan bahwa diversifikasi operasional dan profitabilitas berpengaruh positif dan signifikan terhadap struktur modal. Positif terlihat dari nilai Fhitung sebesar
9,464 > Ftabel sebesar 3,280, dan signifikan yang dilihat dari signifikansi $(0,000)$ lebih kecil dari taraf signifikansi yang disyaratkan sebesar $5 \%(0,05)$. Pengaruh positif menunjukkan bahwa diversifikasi operasional dan profitabilitas sejalan dengan struktur modal, jika diversifikasi operasional dan profitabilitas tinggi maka struktur modal mengalami peningkatan pada perusahaan BUMN sektor perbankan yang terdaftar di bursa efek Indonesia. Berpengaruh signifikan menunjukkan bahwa diversifikasi operasional dan profitabilitas juga memiliki peranan yang sangat penting dalam meningkatkan struktur modal pada perusahaan BUMN sektor perbankan yang terdaftar di bursa efek Indonesia.

Diversifikasi operasional dan profitabilitas juga berpengaruh positif dan signifikan terhadap struktur modal $b$ yang ditunjukkan oleh besanya Fhitung dibanding Ftabel yaitu Fhitung (9,464 > 3,280). Hal ini membuktikan hipotesis penelitian bahwa diversifikasi operasional dan profitabilitas berpengaruh positif dan signifikan terhadap struktur modal pada perusahaan BUMN sektor perbankan yang terdaftar di bursa efek Indonesia. Jika diversifikasi operasional dan profitabilitas tinggi maka struktur modal mengalami peningkatan. Begitu pula sebaliknya apabila diversifikasi operasional dan profitabilitas rendah maka struktur modal menurun. Pada koefisien determinasi $\left(\mathrm{R}^{2}\right)$ yang menunjukkan nilai $R$ Square sebesar 0,526. Hal ini menunjukkan bahwa pengaruh diversifikasi operasional dan profitabilitas terhadap struktur modal adalah sebesar 52,60\%.

Hasil penelitian ini sejalan dengan teori Sutrisno (2013:183), menyatakan 
bahwa struktur modal (capital structure) merupakan perimbangan atau perbandingan antara modal asing atau hutang dengan modal sendiri (debt to equity ratio atau DER) yang digunakan perusahaan untuk membiayai aktivanya. Debt to equity ratio (DER) merupakan rasio yang menggambarkan hutang dengan equitas dalam pendanaan perusahaan dan menunjukkan kemampuan modal sendiri perusahaan tersebut untuk memenuhi kewajibannya. Semakin tinggi rasio DER, maka semakin rendah pendanaan perusahaan yang disediakan oleh pemegang saham. Tinggi rendahnya struktur modal dipengaruhi oleh tinggi rendahnya beberapa faktor seperti diversifikasi operasional.

Penelitian ini juga didukung oleh Lupitasari (2014), yang membuktikan diversifikasi operasional dan profitabilitas berpengaruh positif dan signifikan terhadap struktur modal. Hal ini menunjukkan bahwa diversifikasi operasional dan profitabilitas memiliki peranan yang sangat penting dalam meningkatkan struktur modal pada perusahaan BUMN sektor perbankan yang terdaftar di bursa efek Indonesia.

\section{2) Pengaruh Diversifikasi Operasional terhadap Struktur Modal (H2)}

Hasil penelitian ini menunjukkan bahwa diversifikasi operasional berpengaruh positif dan signifikan terhadap struktur modal. Positif terlihat dari nilai thitung sebesar 3,277 > ttabel sebesar 2,035, dan signifikan yang dilihat dari signifikansi $(0,002)$ lebih kecil dari taraf signifikansi yang disyaratkan sebesar 5\% $(0,05)$. Pengaruh positif menunjukkan bahwa diversifikasi operasional sejalan dengan struktur modal, jika diversifikasi operasional tinggi maka struktur modal mengalami peningkatan pada perusahaan BUMN sektor perbankan yang terdaftar di bursa efek Indonesia. Berpengaruh signifikan menunjukkan bahwa diversifikasi operasional juga memiliki peranan yang sangat penting dalam meningkatkan struktur modal pada perusahaan BUMN sektor perbankan yang terdaftar di bursa efek Indonesia.

Hasil penelitian ini sejalan dengan teori Sutrisno (2013:183), menyatakan bahwa struktur modal (capital structure) merupakan perimbangan atau perbandingan antara modal asing atau hutang dengan modal sendiri (debt to equity ratio atau DER) yang digunakan perusahaan untuk membiayai aktivanya. Debt to equity ratio (DER) merupakan rasio yang menggambarkan hutang dengan equitas dalam pendanaan perusahaan dan menunjukkan kemampuan modal sendiri perusahaan tersebut untuk memenuhi kewajibannya. Semakin tinggi rasio DER, maka semakin rendah pendanaan perusahaan yang disediakan oleh pemegang saham. Tinggi rendahnya struktur modal dipengaruhi oleh tinggi rendahnya beberapa faktor seperti diversifikasi operasional.

Penelitian ini juga didukung oleh Putri Ria (2015), yang menemukan bahwa diversifikasi operasional berpengaruh positif dan signifikan terhadap struktur modal. Hal ini menunjukkan bahwa semakin tinggi diversifikasi operasional maka dapat meningkatkan struktur modal pada perusahaan BUMN sektor perbankan yang terdaftar di bursa efek Indonesia.

\section{3) Pengaruh Profitabilitas terhadap Struktur Modal (H3)}

Hasil penelitian ini menunjukkan bahwa profitabilitas berpengaruh positif dan signifikan terhadap struktur modal. 
Positif terlihat dari nilai thitung sebesar 2,146 > ttabel sebesar 2,035, dan signifikan yang dilihat dari signifikansi $(0,037)$ lebih kecil dari taraf signifikansi yang disyaratkan sebesar $5 \%(0,05)$. Pengaruh positif menunjukkan bahwa profitabilitas sejalan dengan struktur modal, jika profitabilitas tinggi maka struktur modal mengalami peningkatan pada perusahaan BUMN sektor perbankan yang terdaftar di bursa efek Indonesia. Berpengaruh signifikan menunjukkan bahwa profitabilitas juga memiliki peranan yang sangat penting dalam meningkatkan struktur modal pada perusahaan BUMN sektor perbankan yang terdaftar di bursa efek Indonesia.

Hasil penelitian ini sejalan dengan teori Sutrisno (2013:183), menyatakan bahwa struktur modal (capital structure) merupakan perimbangan atau perbandingan antara modal asing atau hutang dengan modal sendiri (debt to equity ratio atau DER) yang digunakan perusahaan untuk membiayai aktivanya. Debt to equity ratio (DER) merupakan rasio yang menggambarkan hutang dengan equitas dalam pendanaan perusahaan dan menunjukkan kemampuan modal sendiri perusahaan tersebut untuk memenuhi kewajibannya. Semakin tinggi rasio DER, maka semakin rendah pendanaan perusahaan yang disediakan oleh pemegang saham. Tinggi rendahnya struktur modal dipengaruhi oleh tinggi rendahnya beberapa faktor seperti diversifikasi operasional.

Penelitian ini juga didukung oleh Ichwan (2015), yang menemukan bahwa profitabilitas berpengaruh positif dan signifikan terhadap struktur modal. Hal ini menunjukkan bahwa semakin tinggi profitabilitas maka dapat meningkatkan struktur modal pada perusahaan BUMN sektor perbankan yang terdaftar di bursa efek Indonesia.

\section{PENUTUP}

\section{a. Simpulan}

Berdasarkan hasil pengujian hipotesis dan mengacu pada perumusan serta tujuan dari penelitian ini, maka dapat ditarik kesimpulan bahwa:

1) Diversifikasi operasional dan profitabilitas secara simultan berpengaruh positif dan signifiakan terhadap struktur modal pada perusahaan BUMN sektor perbankan yang terdaftar di bursa efek Indonesia, hal ini dibuktikan secara statistik Fhitung sebesar 9,464 lebih besar dari Ftabel sebesar 3,280 dan signifikan yang dilihat dari signifikansi sebesar 0,000 lebih kecil dari taraf signifikansi yang disyaratkan sebesar $5 \%(0,05)$.

2) Diversifikasi operasional berpengaruh positif dan signifikan terhadap struktur modal pada perusahaan BUMN sektor perbankan yang terdaftar di bursa efek Indonesia, hal ini dibuktikan secara statistik thitung sebesar 3,277 lebih besar dari ttabel sebesar 2,035 dan signifikan yang dilihat dari signifikansi sebesar 0,002 lebih kecil dari taraf signifikansi yang disyaratkan sebesar 5\% $(0,05)$.

3) Profitabilitas berpengaruh positif dan signifikan terhadap struktur modal pada perusahaan BUMN sektor perbankan yang terdaftar di bursa efek Indonesia, hal ini dibuktikan secara statistik thitung sebesar 2,146 lebih besar dari ttabel sebesar 2,035 dan signifikan yang dilihat dari signifikansi sebesar 0,037 lebih kecil dari taraf signifikansi yang disyaratkan sebesar $5 \%(0,05)$. 


\section{b. Saran}

Berdasarkan hasil penelitian yang telah dilakukan, ada beberapa saran yang dapat dipertimbangkan oleh beberapa pihak:

1) Agar perusahaan memiliki struktur modal yang baik maka perusahaan harus memperhatikan struktur moda. Struktur modal dikatakan baik jika j umlah utang jangka panjang lebih sedikit dibandingkan modal sendiri, sehingga dapat dikatakan aktiva perusahaannya dibiayai oleh modal sendiri yang dimiliki perusahaan tersebut.

2) Dari hasil penelitian ini terlihat bahwa diversifikasi operasional dan profitabilitas secara simultan berpengaruh positif dan signifikan terhadap struktur modal, maka diharapkan pihak pimpinan perusahaan meningkatkan struktur modal pada perusahaan BUMN sektor perbankan yang terdaftar di bursa efek Indonesia.

\section{DAFTAR PUSTAKA}

Agnes, Sawir. (2013). Analisis Kinerja Keuangan dan Perencanaan Keuangan Perusahaan.

Jakarta : Kedua, Penerbit PT. Gramedia Pustaka Utama.

Aisjah, Siti. (2014). Strategi Diversifikasi Korporat: Penciptaan Nilai Perusahaan. Malang : UB Press.

Atami, Aulia. (2013). Pengaruh Diversifikasi dan Good Corporate Govermance terhadap Nilai Perusahaan pada Perusahaan Manufaktur yang Terdaftar di Bursa Efek Indonesia. Skripsi. Semarang : Universitas Diponegoro.

Bramasto, Ari. (2013). Analisis Struktur Modal terhadap Return on Assets pada PT.Pos Indonesia (Persero). Bandung : Jurnal Ekonomi Unikom. 9 (2) 215- 230.

Ghozali, Imam. (2013). Aplikasi Analisis Multivariat dengan Program SPSS. Semarang : Badan Penerbit Universitas Diponegoro.

Hill, C.W.L., Hoskisso, R.E. (2012). "Strategy and Structure In The Multipoduct Firm" Academy of Management Review.

Ichwan. (2015). Pengaruh Diversifikasi Operasional, Struktur Aktiva dan Profitabiitas terhadap

Struktur Modal pada Perusahaan Automotive and Allied Product yang Terdaftar di Bursa Efek Indonesia Tahun 2010-2012). Jurnal Ekonomi. 21 (3).

Ikatan Akuntan Indonesia. (2001). Pernyataan Standar Akuntansi Keuangan (PSAK) No. 5 Revisi 2009. Jakarta : Salemba Empat.

Lupitasari. (2014). Pengaruh Diversifikasi Operasional dan Profitabilitas terhadap Struktur Modal pada Perusahaan yang Terdaftar di Bursa Efek Indonesia Tahun 2010-2012. Jurnal Akuntansi Universitas Udayana. 2 (1).

Mardiyati. (2013). Pengaruh Diversifikasi Operasional dan Profitabilitas terhadap Struktur Modal pada Perusahaan Manufaktur Sub Sektor Otomotif dan Komponenyang Terdaftar di Bursa Efek Indonesia. Jurnal Ekonomi dan Bisnis. 5 (1) 11-20.

Martono, Harjito. (2012). Manajemen Keuangan. Yogyakarta : Edisi 3, Cetakan Ketiga, BPFE.

Nurchanifia. (2014). Pengaruh Diversifikasi Operasional dan Diversifikasi Geografis terhadap Struktur Modal pada Perusahaan Sektor Manufaktur di Bursa Efek 
Indonesia. Jurnal Ilmu dan Riset Akuntansi. 4 (1) Maret.

Putri, Ria. (2015). Pengaruh Diversifikasi Operasional, Profitabilitas dan Struktur Aktiva terhadap Struktur Modal pada Perusahaan Manufaktur Sektor Industri Makanan dan Minuman di Bursa Efek Indonesia. Jurnal Riset Manajemen Sains Indonesia. 3 (1).

Riyanto, Bambang. (2013). Dasar-Dasar Pembelanjaan Perusahaan. Yogyakarta : Penerbit YP. Gajah Mada.

Robert M, Grant. (2010). Analisis Strategi Kontenporer : Konsep, Teknik, Aplikasi. Jakarta : Edisi Kedua, Erlangga.

Sartono, Agus. (2013). Manajemen Keuangan, Teori dan Aplikasi. Yogyakarta : Edisi Keempat, Cetakan Pertama, Penerbit BPFE.

Suad, Husnan. (2011). Seri Penuntun Belajar: Dasar-Dasar Manajemen Keuangan. Yogyakarta : Cetakan Kedua UPP AMP YKPN.

Sugiyono. (2017). Metode Penelitian Bisnis. Bandung : Cetakan Keenambelas. Alfabeta. Sutrisno. (2013). Manajemen Keuangan, Teori, Konsep dan Aplikasi. Yogyakarta : Edisi Pertama, Cetakan Ketiga, Ekonesia

Verawati, Diana. (2014). Pengaruh Diversifikasi Operasi, Diversifikasi Geografi, Leverage terhadap Struktur Modal. Skripsi. Semarang : Universitas Diponegoro. ww.kompas.com. 